\title{
Edukacja dla bezpieczeństwa w zakresie udzielania pierwszej pomocy dla uczniów klasy VIII szkoły podstawowej
}

\author{
Safety education in the field of first aid for 8th grade students \\ of primary school
}

\begin{abstract}
Streszczenie:
Edukacja dla bezpieczeństwa w klasie VIII szkoły podstawowej w zakresie udzielania pierwszej pomocy jest tematem nowatorskim i ważnym dla naszego społeczeństwa. W wieku dorastania uczeń zdobywa wiedzę, rozwija swoje umiejętności i uczy się współpracować zespołowo. Podczas prowadzenia zajęć edukacyjnych w zakresie udzielania pierwszej pomocy należy pamiętać o dostosowaniu poziomu nauczania $\mathrm{z}$ tego zakresu do potrzeb i możliwości uczniów. Celem przeprowadzonych zajęć praktycznych zawsze powinno być utrwalenie schematów postępowania z pierwszej pomocy. Przedmiotem obserwacji uczestniczącej były zastosowane ćwiczenia praktyczne dla uczniów z klasy VIII szkoły podstawowej. Wyniki przeprowadzonych zajęć pokazały zaangażowanie, rozwijanie umiejętności i skuteczności uczniów w zakresie udzielania pierwszej pomocy.
\end{abstract}

Słowa kluczowe: defibrylator treningowy AED, konkursy z pierwszej pomocy, scenariusz zajęć z pierwszej pomocy, zajęcia edukacyjne z pierwszej pomocy, fantom

\begin{abstract}
:
Safety education in the 8th grade of primary school in the field of first aid is an innovative and important subject for our society. Adolescent pupils acquire knowledge, develop skills and learn to collaborate in a team. While conducting educational classes in the field of first aid it is important to remember to adjust the level of teaching to the needs and abilities of the students. The aim of practical classes should always be to consolidate the protocols of first aid treatment. The subject of participant observation
\end{abstract}


Michał Mikulski - Edukacja dla bezpieczeństwa...

were practical exercises for pupils from the 8th grade of primary school. The results of the classes showed the pupils' involvement and skill development as well as effectiveness in the field of first aid.

Keywords: AED training defibrillator, first aid competitions, first aid class scenario, first aid educational activities, phantom

\section{Wprowadzenie}

Nowa reforma oświaty wprowadziła od roku szkolnego 2018/2019 edukację dla bezpieczeństwa dla klas VIII szkoły podstawowej. Zgodnie z podstawą programową ${ }^{1}$ jednym z ogólnych celów kształcenia jest kształtowanie umiejętności z zakresu podstaw udzielania pierwszej pomocy. Szkoły podstawowe są zobowiązane zapewnić uczniom klas 8. zajęcia $\mathrm{z}$ pierwszej pomocy $\mathrm{w}$ ramach edukacji dla bezpieczeństwa. Zgodnie z ustawą ${ }^{2}$ zajęcia edukacyjne $\mathrm{w}$ zakresie udzielania pierwszej pomocy są realizowane z udziałem: lekarza systemu, pielęgniarki systemu lub ratownika medycznego. Ustawodawca dopuścił również udział nauczyciela posiadającego odpowiednie przygotowanie do prowadzenia tych zajęć.

Ważna jest edukacja, która uczy ratowania życia. Pozwala młodemu człowiekowi poznać i zrozumieć jasne schematy działania w zakresie udzielania pierwszej pomocy. System ratowniczy jest w Polsce bardzo rozwinięty. Szczególnym przykładem jest Górskie Ochotnicze Pogotowie Ratunkowe (GOPR), w którym ratownicy wykonują na bieżąco ćwiczenia, pozoracje tak, aby umieć udzielić pomocy na wypadek nieoczekiwanego zdarzenia w górach. Współpraca szkoły podstawowej z GOPR pokazuje, że uczniowie nie mają żadnych barier, aby w uzasadnionych przypadkach wezwać służby ratunkowe, dzwoniąc pod numer 601100 300, 985 lub skorzystać z aplikacji „Ratunek”. Uczniowie klas VIII nie mają oporu przed udzielaniem pierwszej pomocy, podczas gdy osoby dorosłe mają bardzo dużo lęku i obaw przed konsekwencjami

\footnotetext{
1 Dz.U. z dnia 24 lutego 2017 r., poz. 356.

${ }^{2}$ Art. 8 Ustawy z dnia 8 września 2006 r. z późn. zm. o Państwowym Ratownictwie Medycznym (Dz.U. z 2006 r., nr 191, poz. 1410).
} 
prawnymi, co często sprowadza do tego, że jedynie dzwonią pod numer 112 i nie robią nic, aby zapobiec nieszczęściu. Uczniowie powinni mieć zajęcia praktyczno-edukacyjne $\mathrm{w}$ zakresie udzielania pierwszej pomocy w służbach, organizacjach ratowniczych, aby mogli zobaczyć i poznać ludzi, którzy na co dzień ratują ludzkie życie, wyjeżdżając do pożarów, wypadków, skażeń chemicznych oraz innych zdarzeń. Ćwiczenia te uczą współpracy, szczególnie podczas realizacji zajęć z edukacji dla bezpieczeństwa.

\section{Zajęcia edukacyjne z pierwszej pomocy}

Przed poprowadzeniem zajęć edukacyjnych z zakresu udzielania pierwszej pomocy należało zadać sobie następujące pytania, niezbędne w obserwacji uczestniczącej:

1. Jaki poziom wiedzy mają uczniowie klasy VIII z pierwszej pomocy?

2. W jaki sposób uczniowie klasy VIII uczą się resuscytacji krążeniowo-oddechowej u osoby dorosłej?

3. W jaki sposób uczniowie klasy VIII uczą się zastosowania standardowej pozycji bocznej bezpiecznej u osoby nieprzytomnej, oddychającej?

4. W jaki sposób uczniowie uczą się postępować na miejscu wypadku komunikacyjnego?

5. Czy uczniowie wiedzą, w jakich przypadkach i jak należy posługiwać się defibrylatorem AED?

6. W jaki sposób uczniowie mogą sprawdzić swoją wiedzę zdobytą podczas zajęć?

Treścią obserwacji uczestniczącej mogą być zagadnienia dotyczące:

- oceny własnego bezpieczeństwa,

- zapewnienia pomocy,

- reakcji uczniów na niebezpieczeństwo,

- rozpoznawania symptomów zagrożenia,

- zachowania uczniów w sytuacji zagrożenia życia i zdrowia, 
Michał Mikulski - Edukacja dla bezpieczeństwa...

- udzielania pierwszej pomocy, wykonywania resuscytacji krążeniowo-oddechowej,

- reakcji na komunikaty wydawane przez defibrylator AED.

Podczas zajęć należy zwracać szczególną uwagę na przebieg ćwiczeń dla uczniów oparty na wytycznych ${ }^{3}$ :

1. Sprawdzenie własnego bezpieczeństwa i podejście do osoby poszkodowanej.

2. Ocena przytomności u osoby poszkodowanej.

3. Wołanie o pomoc.

4. Udrażnianie dróg oddechowych poprzez odciągnięcie głowy do tyłu.

5. Ocenianie oddechu przez 10 sek.

6. Rozmowa z dyspozytorem służb ratowniczych (numer 999 lub 112).

7. Przystąpienie do resuscytacji krążeniowo-oddechowej (30 uciśnięć klatki piersiowej i wykonania 2 oddechów ratowniczych).

8. Ułożenie osoby poszkodowanej w pozycji bocznej bezpiecznej.

9. Używanie defibrylatora AED podczas ćwiczeń z resuscytacji krążeniowo-oddechowej.

Przeprowadzone zajęcia edukacyjne z zakresu udzielania pierwszej pomocy dla uczniów klasy VIII szkoły podstawowej pozwoliły odpowiedzieć prowadzącemu zajęcia na postawione wcześniej pytania, a następnie sformułować odpowiednie wnioski.

${ }^{3}$ Zob. http://www.prc.krakow.pl/wyt2015/2_BLS.pdf [dostęp: 30-05-2020]. 


\section{Przykładowy autorski scenariusz zajęć z pierwszej pomocy dla uczniów klasy VIII szkoły podstawowej}

\section{Temat: Wypadki komunikacyjne ${ }^{4}$}

Klasa VIII szkoły podstawowej

\section{Cele ogólne:}

- Poznanie przyczyn i zagrożeń wypadków komunikacyjnych.

- Pozoracje wypadku komunikacyjnego i postępowanie ratownicze na miejscu zdarzenia.

Cele szczegółowe - uczeń5:

- Wymienia główne przyczyny wypadków komunikacyjnych.

- Opisuje zagrożenia towarzyszące tym wypadkom.

- Wymienia czynności, które należy wykonać, aby ocenić sytuację na miejscu zdarzenia i stosuje tę wiedzę w praktyce.

- Omawia sposoby zapewnienia bezpieczeństwa poszkodowanym, ratownikowi, osobom postronnym i w miejscu zdarzenia.

- Omawia podstawowe zasady postępowania ratownika w miejscu zdarzenia (wypadek komunikacyjny).

Czas realizacji: 1 dzień

Miejsce: sala lekcyjna

Metody: słowne, praktyczne, pokaz, ćwiczenia ${ }^{6}$

Formy: indywidualne i grupowe

\footnotetext{
4 Podstawa programowa edukacji dla bezpieczeństwa dla klas VIII, Dz.U. z dnia 24 lutego 2017 r., poz. 356.

5 J. Słoma, Żyję i działam bezpiecznie. Podręcznik do edukacji dla bezpieczeństwa dla szkoły podstawowej, Warszawa 2017, s. 54-59.

${ }^{6}$ J. Ropski, Jak przygotować się do lekcji? Edukacja dla bezpieczeństwa. Poradnik metodyczny dla nauczycieli i studentów, Katowice 2012, s. 95.
} 
Michał Mikulski - Edukacja dla bezpieczeństwa...

Pomoce dydaktyczne: kamizelka odblaskowa, opaski odblaskowe, apteczka pierwszej pomocy, trójkąt ostrzegawczy, fantom do nauki resuscytacji krążeniowo-oddechowej, defibrylator treningowy AED, schemat działań-wypadek drogowy.

\section{Przebieg zajęć:}

1. Czynności organizacyjne: powitanie uczniów, sprawdzenie listy obecności. Rozdanie uczniom schematu działań-wypadek drogowy (Rys. 1).

2. Omówienie przez nauczyciela tematu, a następnie wymienienie przez uczniów głównych przyczyn i skutków wypadków komunikacyjnych.

3. Nauczyciel pokazuje i omawia na fantomie znajdującym się w makiecie samochodu, w jaki sposób należy zachować się na miejscu wypadku komunikacyjnego ${ }^{7}$, zwracając szczególną uwagę na bezpieczeństwo ratownika.

4. Prowadzący wybiera spośród uczniów grupę, której zadaniem jest przećwiczenie zadania. Podczas ćwiczeń nauczyciel w oparciu o kartę oceny zawartą w scenariuszu $31^{8}$ sprawdza umiejętności praktyczne uczniów w zakresie wypadku komunikacyjnego.

5. Zakończenie zajęć: omówienie ćwiczeń praktycznych, nagrodzenie aktywnych uczniów plusami lub ocenami w zależności od zaangażowania i posiadanej wiedzy.

\footnotetext{
${ }^{7}$ A. Mikołajczak, Pierwsza pomoc. Ilustrowany poradnik, Poznań 2019, s. 25-29.

8 M. Chomoncik, U. Cisoń-Apanasewicz, P. Kuchnia, J. Nitecki, Pomoc przedszpitalna. Scenariusze ćwiczeń, Warszawa 2018, s. 68.
} 
Rys. 1. Wypadek drogowy - schemat działań

\section{WYPADEK DROGOWY}

Pamiętaj o bezpieczeństwie w miejscu wypadku!

1. Zaparkuj swój samochód w miejscu bezpiecznym i włącz w nim światła awaryjne.

2. Zabezpiecz miejsce wypadku ostrzegawczym trójkątem odblaskowym lub wyślij kogoś. Trójkąt umieszcza się na drodze za pojazdem w odległości:

- Na autostradzie i drodze ekspresowej $100 \mathrm{~m}$,

- Poza obszarem zabudowanym 30-50m,

- Na obszarze zabudowanym za pojazdem lub na nim na wysokości nie większej

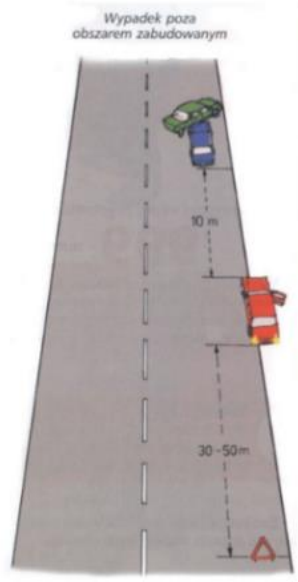
niż $1 \mathrm{~m}$.

3 W uszkodzonym samochodzie wyłącz stacyjkę i zaciagnij hamulec. Zgaś dostrzeżonego papierosa. Odłącz akumulator. Ustaw samochód w stabilnym położeniu.

4. Zbadaj osoby poszkodowane. Zwróć uwage na to, aby poszkodowani mieli drożne drogi oddechowe. Jeżeli trzeba, to wezwij pogotowie ratunkowe - 999 lub 112

5. Udziel odpowiedniej pomocy, tj. wynikającej ze stanu i urazu poszkodowanego

Źródło: http://scholaris.pl/resources/run/id/54682 [dostęp 30-05-2020].

\section{Sprzęt dydaktyczny:}

Na zajęciach konieczne było oprócz teoretycznych założeń przygotowanie dla uczniów specjalistycznego sprzętu dydaktycznego. Sprzęt składał się z:

a) fantomu „Little Anne QCPR” osoby dorosłej,

b) defibrylatora treningowego AED.

Uczniowie słuchali i wykonywali polecenia defibrylatora, który był sterowany przez nauczyciela. 
Michał Mikulski - Edukacja dla bezpieczeństwa...

Zdjęcie 1. Fantom „Little Anne QCPR” osoby dorosłej

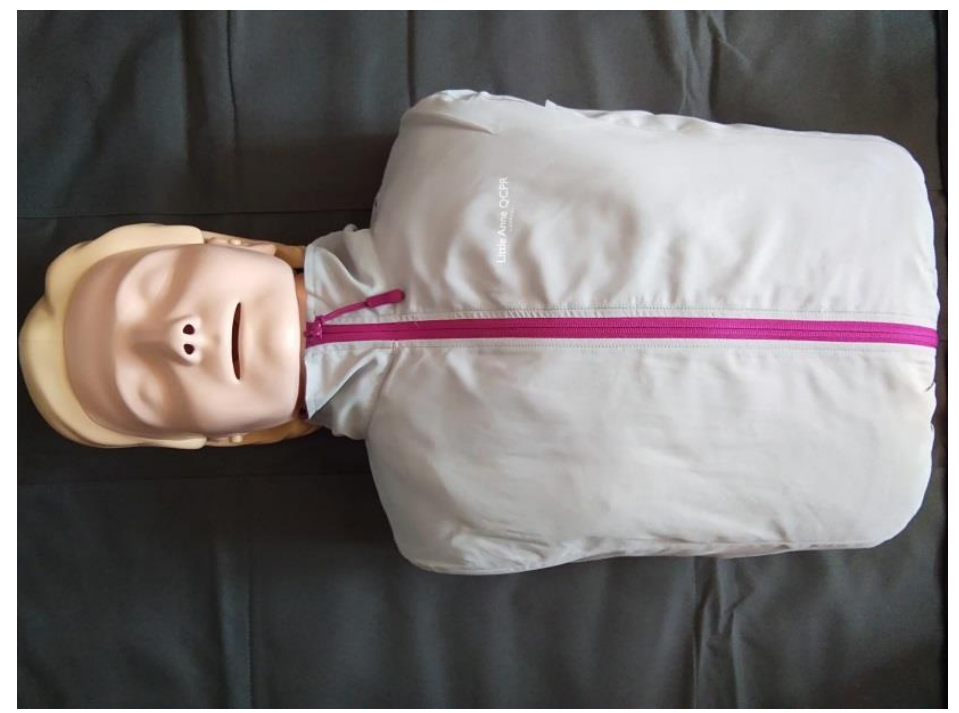

Źródło: opracowanie własne.

Zdjęcie 2. Defibrylator treningowy AED

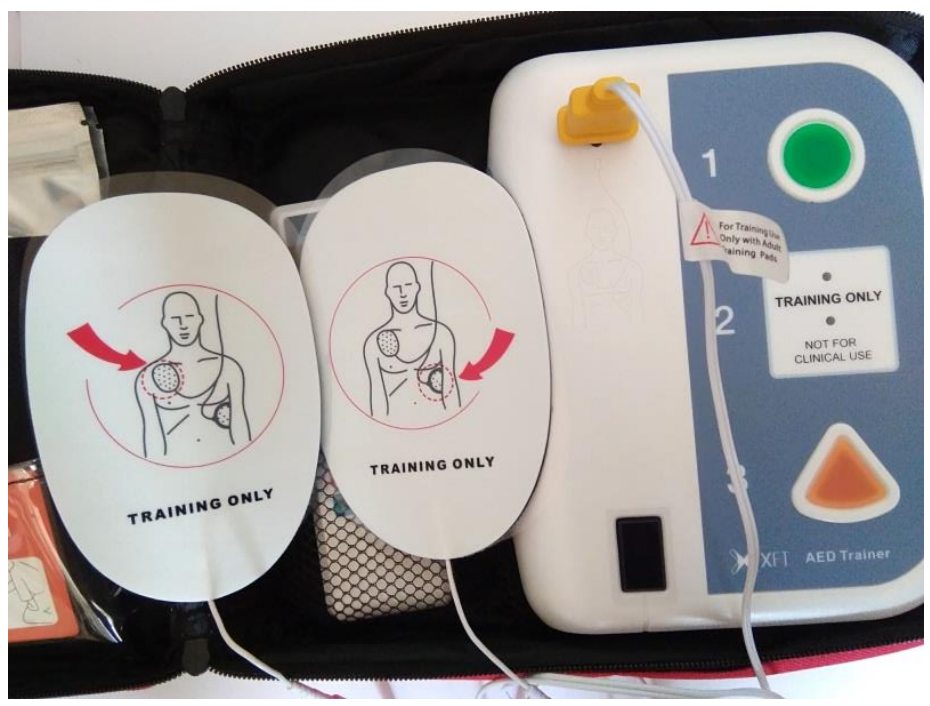

Źródło: opracowanie własne. 
Na podstawie wyników przeprowadzonej przeze mnie obserwacji uczestniczącej w terminie 23.11.2018-14.06.2019 mogłem stwierdzić, iż uczniowie klasy VIII Szkoły Podstawowej nr 100 im. płk. Francesco Nullo w Warszawie potrafią udzielać pierwszej pomocy w sytuacji zatrzymania akcji serca u osoby dorosłej przy użyciu AED. Przeprowadzone ćwiczenia miały na celu utrwalenie schematów postępowania w sytuacji wypadku komunikacyjnego, kiedy osoba jest nieprzytomna i nie oddycha. Przebieg zajęć edukacyjnych z zakresu udzielania pierwszej pomocy pozwolił na udzielenie odpowiedzi na poniższe pytania.

\section{Jaki poziom wiedzy maja uczniowie klas VIII z pierwszej pomocy?}

Uczniowie klas ósmych mają znaczną wiedzę na temat postępowania w sytuacji zagrożeń. Przy omawianiu wyposażenia apteczki potrafili wymienić i opowiedzieć, do czego służy wyposażenie podstawowych barier ochrony osobistej, którymi są: rękawiczki, maseczka do sztucznego oddychania, maseczka typu „Pocet Mask”, bandaże, chusty trójkątne, opatrunki jałowe, szyny Kramera itp. Są zainteresowani i zaciekawieni poznawaniem zasad udzielania pierwszej pomocy szczególnie z użyciem fantomu do nauki resuscytacji krążeniowo-oddechowej „Little Anne QCPR” (Zdjęcie 1). Manekin odwzorowywał osobę poszkodowaną, na której uczniowie wykonywali praktyczne ćwiczenia z resuscytacji krążeniowo-oddechowej.

\section{W jaki sposób uczniowie klas VIII uczą się resuscytacji krążeniowo- oddechowej u osoby dorosłej?}

Uczniowie uczą się resuscytacji krążeniowo-oddechowej u osoby dorosłej poprzez zaprezentowanie następującego schematu udzielania pierwszej pomocy. 
Michał Mikulski - Edukacja dla bezpieczeństwa...

Schemat 1. Postępowanie w zatrzymaniu krążenia u osób dorosłych przy zastosowaniu AED

\section{SPRAWDŹ BEZPIECZEŃSTWO}

OCEŃ PRZYTOMNOŚĆ

WOŁAJO POMOC

UDROŻNIJ DROGI ODDECHOWE

OCEŃ ODDECH-PRZEZ 10 sek.

JEŚLI NIE ODDYCHA

ZADZWOŃ

pod numer 999 LUB 112

Jeśli nie jesteś sam, wyślij kogoś po defibrylator AED

30 UCIŚNIĘĆ KLATKI PIERSIOWEJ

2 ODDECHY RATUNKOWE

W sytuacji, kiedy defibrylator AED został przyniesiony włącz go

i wykonuj jego polecenia

Źródło: Opracowanie własne na podstawie wytycznych z 2015 r. Polskiej Rady Resuscytacji

Podczas ćwiczeń wyjaśniono uczniom, że resuscytację krążeniowooddechową wykonujemy do chwili, kiedy:

a) przejmą od nas osobę poszkodowaną służby ratownicze;

b) stracimy własne siły - wykonywanie masażu serca i oddechów ratowniczych wymaga od ratownika dużej pracy fizycznej, dlatego ważne jest zapewnienie osoby dodatkowej, która może nas zmienić, tzn. jedna osoba wykonuje wówczas masaż serca, a druga oddechy ratownicze; 
c) zagraża nam niebezpieczeństwo, np. kiedy ktoś próbuje nas zaatakować;

d) osoba poszkodowana zacznie sama oddychać.

W jaki sposób uczniowie klas VIII uczą się zastosowania standardowej pozycji bocznej bezpiecznej u osoby nieprzytomnej, oddychajacej?

Została pokazana pozycja boczna bezpieczna, a następnie uczniowie ćwiczyli ją na sobie w parach. Uczniowie klas VIII chętnie wykonują ćwiczenia w zespołach dwuosobowych według następujących czynności:

- Sprawdź własne bezpieczeństwo;

- Oceń przytomność osoby poszkodowanej;

- Wołaj o pomoc lub jeżeli nie jesteś sam wyznacz osobę, która Ci pomoże;

- Udrożnij drogi oddechowe poprzez wysunięcie głowy do tyłu;

- Przyłóż swoje ucho pomiędzy nos a usta osoby poszkodowanej, patrząc cały czas na klatkę piersiową osoby poszkodowanej i oceń oddech przez 10 sek.;

- Poszkodowany oddycha, ułóż osobę w pozycji bocznej bezpiecznej, okryj folią termoizolacyjną;

- Zawiadom służby ratownicze pod numerem 999 lub 112 i czekaj do ich przyjazdu.

Wszyscy uczniowie umieli zastosować poprawnie ww. czynności. Na końcu uczniowie przykrywali osobę poszkodowaną folią termoizolacyjną służącą do utrzymywania komfortu cieplnego.

\section{W jaki sposób uczniowie uczą się postępować na miejscu wypadku komunikacyjnego?}

Dobrze przystosowana i wyposażona sala lekcyjna ułatwia naukę pierwszej pomocy w przypadku wypadku komunikacyjnego. Należy zadbać o odpowiedni sprzęt dydaktyczny służący do symulacji wypad- 
Michał Mikulski - Edukacja dla bezpieczeństwa...

ku, w tym przypadku może to być np. rower, fantom, kask rowerowy, apteczka pierwszej pomocy, zestaw do pozoracji ran, kamizelka odblaskowa, makieta ulicy, trójkąt ostrzegawczy oraz makieta samochodu. Uczniowie klas VIII bardzo chwalą sobie ćwiczenia praktyczne oraz symulacje różnych zdarzeń, dzięki którym zapamiętują schemat udzielania pomocy.

Czy uczniowie wiedza, w jakich przypadkach i jak należy posługiwać się defibrylatorem AED?

Prowadzone ćwiczenia z resuscytacji krążeniowo-oddechowej wymagały zastosowania defibrylatora treningowego AED (Zdjęcie 2). Uczniowie w zespołach dwuosobowych testowali defibrylator treningowy. Sprzęt wydawał polecenia głosowe, stąd uczniowie wiedzieli, jak mają postąpić $\mathrm{w}$ danej sytuacji. Uczniowie odklejali elektrody oraz przyklejali je na fantomie w odpowiednich miejscach wskazanych na elektrodach na rysunku. Następnie na polecenie „cofnąć się, trwa wyładowanie" zachowali bezpieczną odległość i cofali się. Uczniowie wiedzą, gdzie na co dzień znajdują się defibrylatory. Najczęściej padały odpowiedzi: na dworcu, w metrze oraz w centrum handlowym.

\section{W jaki sposób uczniowie moga sprawdzić swoją wiedzę zdobyta podczas zajęć?}

Uczniowie mogą sprawdzić wiedzę z pierwszej pomocy zdobytą podczas zajęć z edukacji dla bezpieczeństwa np. podczas turniejów, konkursów, mistrzostw z zakresu udzielania pierwszej pomocy. Cennym doświadczeniem dla uczniów klasy VIII był udział w XVII Ogólnopolskim Turnieju Wiedzy „Pierwsza Pomoc”, który odbył się 20 maja 2019 r. w Nowej Rudzie. Organizatorem turnieju było Stowarzyszenie Komitet Obywatelski Ziemi Kłodzkiej. Symulacje różnych zdarzeń, wypadków, utraty przytomności, omdlenia, udaru, urazu kręgosłupa itp. pozwoliły uczniom $\mathrm{w}$ grupie czteroosobowej sprawdzić się $\mathrm{w}$ roli ratownika. Zwycięstwo w tym turnieju i zajęcie trzeciego miejsca w Polsce w kategorii poniżej 16 roku życia (Zdjęcie 3) okazało się dla 
zespołu cenną lekcją, doświadczeniem, radzeniem w trudnych sytuacjach i umiejętnością współpracy między sobą.

Zdjęcie 3. Zajęcie III miejsca w Polsce w kategorii poniżej 16 roku życia

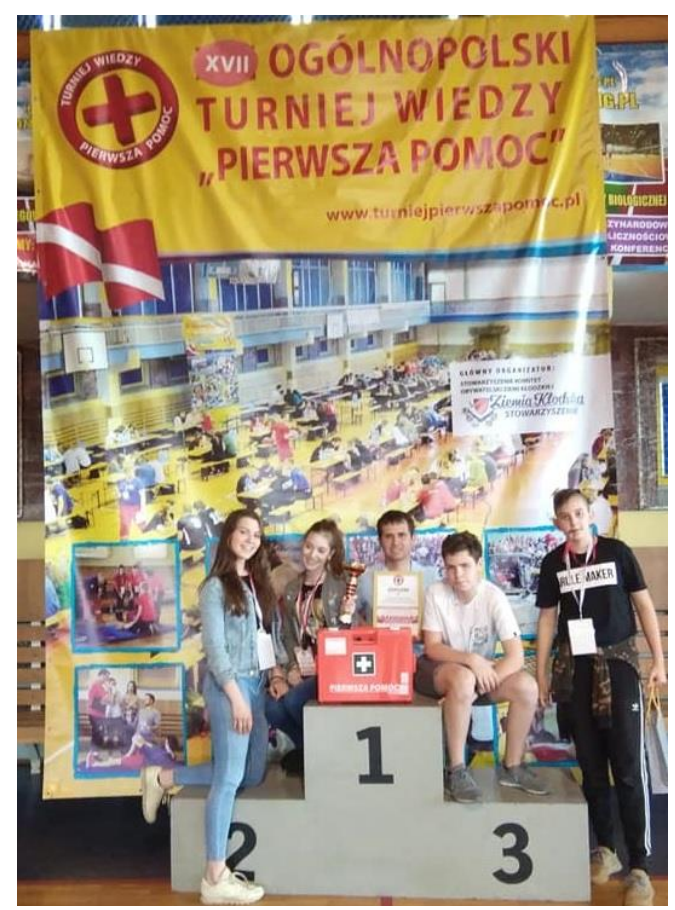

\section{Źródło:}

https://www.facebook.com/1368338936540495/photos/a.1651737201533999/27 63685773672464/?type=3\&theater [dostęp: 31-05-2020].

Dla najlepszych uczestników XVII Ogólnopolskiego Turnieju Wiedzy „Pierwsza Pomoc” była przewidziana nagroda w postaci szkolenia z zakresu ratownictwa w warunkach górskich (Zdjęcie 4), które odbyło się 10-11.06.2019 r. w Sokolcu (gm. Nowa Ruda). Uczniowie pod opieką ratowników Górskiego Ochotniczego Pogotowia Ratunkowego Grupy Wałbrzysko-Kłodzkiej ćwiczyli udzielanie pomocy w górach oraz sposoby transportowania osób poszkodowanych. 


\section{Michał Mikulski - Edukacja dla bezpieczeństwa...}

Zdjęcie 4. Szkolenie z ratownictwa w warunkach górskich

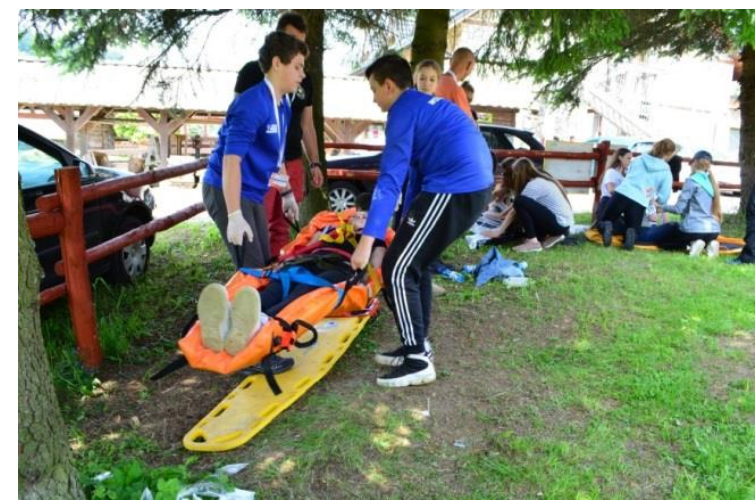

\section{Źródło:}

https://www.facebook.com/turniejpierwszapomoc/photos/a.2419340448127403/2 419367748124673/?type=3\&theater [dostęp: 31-05-2020].

\section{Podsumowanie}

Zajęcia z edukacji dla bezpieczeństwa uczniów klasy VIII w zakresie udzielania pierwszej pomocy w Szkole Podstawowej nr 100 im. płk. Francesco Nullo w Warszawie były udanymi zajęciami. Uczniowie mają znaczną wiedzę na temat udzielania pierwszej pomocy, którą można wykorzystać do zajęć edukacyjnych. Celem obserwacji uczestniczącej było udowodnienie, że uczniowie potrafią:

a) zastosować resuscytacje krążeniowo-oddechową u osoby nieprzytomnej i nieoddychającej;

b) zastosować pozycję boczną bezpieczną u osoby nieprzytomnej, lecz oddychającej;

c) współpracować w grupie i prowadzić resuscytacje krążeniowooddechową z użyciem defibrylatora treningowego AED, wykonywać polecenia defibrylatora, nakleić odpowiednio elektrody na fantomie zgodnie z obrazkiem przedstawionym na elektrodzie;

d) postępować na miejscu wypadku komunikacyjnego;

e) posługiwać się apteczką pierwszej pomocy przy opatrywaniu krwotoków, złamań, zwichnięć i innych urazów. 
Obserwacja uczestnicząca została specjalnie przygotowana, aby można było stwierdzić, czy uczniowie klas VIII szkoły podstawowej potrafią udzielać pierwszej pomocy. Praktyczne ćwiczenia są najlepszą metodą, która uczy, jak ratować ludzkie życie. Uczniowie mogą sprawdzać wiedzę zdobytą podczas zajęć w różnych turniejach, konkursach i szkoleniach z zakresu udzielania pierwszej pomocy, ratownictwa wodnego, górskiego itp. Właśnie pierwsza pomoc uczy pracy zespołowej, radzenia sobie w trudnych sytuacjach, w których czasami jesteśmy zdani tylko na siebie.

\section{Bibliografia:}

Ustawa z dnia 8 września 2006 r. z późn. zm. o Państwowym Ratownictwie Medycznym (Dz.U. z 2006 r., nr 191, poz. 1410).

Chomoncik M., Cisoń-Apanasewicz U., Kuchnia P., Nitecki J., Pomoc przedszpitalna. Scenariusze ćwiczeń, wyd. I, PZWL Wydawnictwo Lekarskie, Warszawa 2018.

Mikołajczak A., Pierwsza pomoc. Ilustrowany poradnik, Wyd. Publicat S.A., Poznań 2019.

Mikulski M., Edukacja dla bezpieczeństwa uczniów w wieku wczesnoszkolnym w zakresie udzielania pierwszej pomocy, [w:] J. Wojciechowski (red.) Strategia Bezpieczeństwa Narodowego $w$ ujęciu interdyscyplinarnym, t. II, Wydawnictwo PWSZ we Włocławku, Włocławek 2018.

Kubiak K., Mickiewicz P. (red.), Edukacja dla bezpieczeństwa. Przewodnik dla nauczycieli, wyd. II uzupełnione, Wyd. Akademickie AMW, Gdynia 2017.

Ropski J., Jak przygotować się do lekcji? Edukacja dla bezpieczeństwa. Poradnik metodyczny dla nauczycieli i studentów, Wyd. AWF Katowice, Katowice 2012.

Podstawa programowa edukacji dla bezpieczeństwa dla klas VIII, Dz.U. z dnia 24 lutego 2017 r., poz. 356.

Słoma J., Żyję i działam bezpiecznie. Podręcznik do edukacji dla bezpieczeństwa dla szkoły podstawowej, Wyd. Nowa Era, Warszawa 2017. 
Michał Mikulski - Edukacja dla bezpieczeństwa...

\section{Netografia:}

Oficjalna strona internetowa Polskiej Rady Resuscytacji, wytyczne 2015 http://www.prc.krakow.pl/wyt2015/2_BLS.pdf [dostęp: 30-05-2020]. http://scholaris.pl/resources/run/id/54682 [dostęp 30-05-2020]. https://www.facebook.com/1368338936540495/photos/a.165173720153 3999/2763685773672464/?type=3\&theater [dostęp 31-05-2020]. https://www.facebook.com/turniejpierwszapomoc/photos/a.24193404481 27403/2419367748124673/?type=3\&theater [dostęp 31-05-2020]. 